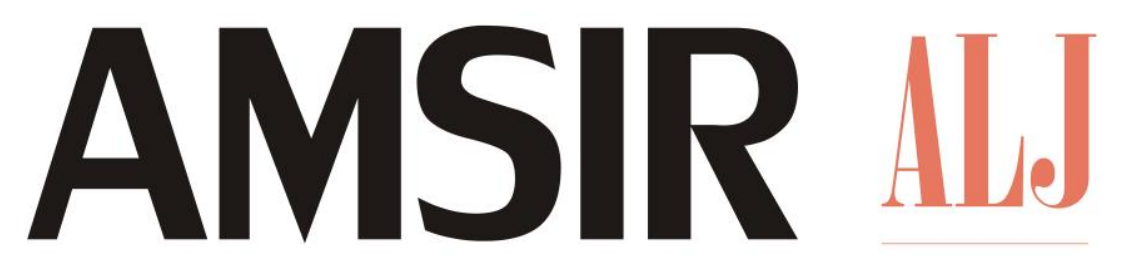

Volume 2

Issue 2

April, 2021

\title{
Health Protocol Sanctions Policy in Sorong Mayor Regulation
}

\author{
Alwiyah Sakti Ramdhon Syah Rakia1.
}

\section{ARTICLE INFO}

\section{Keywords:}

Health Protocol; Sanctions

Policy; Sorong Mayor's

Regulation; Covid-19.

How to cite:

Rakia, Alwiyah Sakti

Ramdhon Syah. (2021).

Health Protocol Sanctions

Policy in Sorong Mayor

Regulation. Amsir Law

Journal, 2(2), 69-78.

DOI:

$10.36746 /$ alj.v2i2.38

\section{ABSTRACT}

This study aims to analyze the policy of legal sanctions of public bealth protocols in Article 7 of Sorong Mayor Regulation Number 17 of 2020. This study uses normative research that is qualitatively analyzed. This research uses a legal approach. The results of this study show that sanctions in the form of monetary fines as stipulated in Article 7 paragraph (2) letter a have no firm legal basis and tend to potentially interfere with economic activities to improve the welfare of the people, especially in the era of the covid19 pandemic.

\section{Introduction}

The spread of Corona Virus Disease 2019 (Covid-19) has hit many countries in the world, causing instability in various fields of human life, even causing death. In Indonesia itself, as described in a study, ${ }^{2}$ it is stated that Indonesia has experienced conditions where the public's concern about covid-19 is quite large so that a government policy is needed to carry out a lockdown, as an effort to break the chain of the spread of the covid-19 coronavirus. The government, to stop the spread of covid-19, has made many policies in various fields with different types and forms of regulations and decisions that are adjusted to the types and forms of policies that have been set. There are variations in the forms and types of regulations, decisions, and government actions due to their formation in extraordinary circumstances, which are different from normal conditions.

At the regional level, the central government policies have been responded to by the regions by implementing some of the policies, including "lockdown" policy, based on

\footnotetext{
${ }^{1}$ Faculty of Law in University of Muhammadiyah Sorong, Sorong, Indonesia.E-mail: saktialwiyah@um-sorong.ac.id .

2 N. R. Yunus and A. Rezki. (2020). Kebijakan Pemberlakuan Lockdown sebagai Antisipasi Penyebaran Corona Virus Covid-19. SALAM: Jurnal Sosial \& Budaya Syar-i, 7(3): 227-238. doi: https://doi.org/10.15408/sjsbs.v7i3.15083 .
} 
Government Regulation Number 21 of 2020. The "lockdown" policy in Article 3 Government Regulation Number 21 of 2020 must meet at least two criteria.

1) The number of cases or the number of deaths due to the disease has increased and spread significantly and rapidly to several regions.

2) There is an epidemiological link with similar incidents in other regions or countries. Furthermore, in Article 4 of Government Regulation Number 21 of 2020, it is determined that the "lockdown" covers at least (a) school holidays; (b) restrictions on religious activities; and (c) restrictions on activities in public places or facilities.

The implementation of the "lockdown" is also determined to consider the education needs, work productivity, and worship of the population, as well as to pay attention to the fulfilment of the basic needs of the population. The implementation of regional "lockdown" is based on the provisions of Article 6 Government Regulation Number 21 of 2020 , proposed by the governor, regent, or mayor to the minister who holds government affairs in the health sector. Furthermore, the minister who carries out government affairs in the health sector in determining the "lockdown" must pay attention to the considerations of the Chief Executive of the Covid-19 Task Force.

The Chief Executive of the Covid-19 Task Force can also propose to the minister who carries out government affairs in the health sector to determine the "lockdown" in certain areas, and if approved, the regional head is obliged to implement the "lockdown". This means that it is possible to determine the "lockdown" without being preceded by a proposal by the governor, regent or mayor.

The West Papua Region as one of the regions in Indonesia that are also exposed to covid-19 has also implemented a "lockdown" with several restrictions related to public activities. The latest data shows that in West Papua Province there are 3,858 cases or around $1.0 \%$ of the total distribution in Indonesia. As of 23 October, since this text was written, there has been an increase in the number of cases in West Papua by 97 cases. ${ }^{4}$ One area in West Papua Province, namely Sorong City, as of October 23, based on data released by the covid-19 task force in Sorong, there are 1.707 confirmed cases of covid-19. ${ }^{5}$ In other words, $0,7 \%$ were exposed to covid-19 of the total population in Sorong, which amounted to 254.294 people. $^{6}$

One of the policy instruments set by the Sorong Government is to stipulate regulation of the Mayor of Sorong Number 17 of 2020 concerning the Implementation of Discipline and Law Enforcement of Health Protocols as Efforts to Prevent and Control Covid-19. In the consideration of considering, it is stated that this policy is in the context of implementing Presidential Instruction Number 6 of 2020 and Instruction of the Minister of Home Affairs Number 4 of 2020. Besides, it is also stated that increasing the application of disciplines for prevention and transmission of covid-19 by imposing sanctions on health offenders due to the increasing number of positive cases and the low compliance of the community and employers in implementing health protocols.

\footnotetext{
3 Article 6 Paragraph (3) and (4) Government Regulation Number 21 of 2020.

${ }^{4}$ Komite Penanganan Covid-19 dan Pemulihan Ekonomi Nasional (KPCPEN). (2020). Peta Sebaran Covid-19. Available online from: https:// covid19.go.id/peta-sebaran. [Accessed October 23, 2020].

${ }^{5}$ KOMPAS. (2020). Data Terbaru Covid-19 Kota Sorong. Available online from: bttps:// wnw.kompas.tv/article/118180/dataterbaru-covid-19-kota-sorong. [Accessed October 23, 2020].

${ }^{6}$ Badan Pusat Statistik (BPS) Kota Sorong. (2020). Jumlah Penduduk Menurut Jenis Kelamin dan Distrik di Kota Sorong, $2015-$ 2019. Available from: https://sorongkota.bps.go.id/dynamictable/2018/10/09/134/jumlah-penduduk-menurut-jenis-kelamin-dandistrik-di-kota-sorong-2015---2019.html. [Accessed October 23, 2020].
} 
It is stated in a quo regulation that the scope of this regulation includes implementation, monitoring and evaluation, sanctions, socialization and participation, and funding. Meanwhile, the subject of regulations includes individuals, business actors, and managers, organizers or persons in charge of business premises and public facilities. All subjects of the arrangement referred to are required to carry out and prepare the means and infrastructure in the case of wearing a mask, washing hands, maintaining distance, and avoiding crowds. In terms of monitoring and evaluating a quo regulatory policy, the Mayor has assigned the Covid-19 Task Force for Sorong and assisted by Pamong Praja Police.

The interesting thing in Mayor of Sorong Number 17 of 2020, which is related to the existence of the content of Article 7 paragraph (2) letter a Mayor of Sorong Number 17 of 2020 which regulates individual sanctions that are different from the managers, organizers or people in charge of business places and public facilities, which consist of social sanctions; and sanctions in the form of monetary fines with different amounts. The subject of a quo rule who is subject to sanctions is given a fine stipulation letter based on evidence of violation given to the violator. Money fines obtained from the application of these sanctions will then be deposited to the regional treasury.

The existence of Article 7 paragraph (2) letter a Mayor of Sorong Number 17 of 2020 which contains regulations regarding sanctions against individuals have received various responses from many groups. In general, the position of Article 7 of Mayor of Sorong Number 17 of 2020 as a whole which contains sanctions is considered inappropriate, if it is reviewed based on Article 15 of Law Number 12 of 2011 concerning the Formation of Laws and Regulations, as amended by Law Number 15 of 2019 concerning Amendments to Law Number 12 of 2011 concerning the Formation of Legislative Regulations. Likewise, in Law Number 9 of 2015 concerning Second Amendment to Law Number 23 of 2014 concerning Regional Government, there is no legal norm that explicitly regulates the preparation of material for sanctions in the formation of a mayor regulation.

If further investigated into the policy that gives authority in the formation of material for sanctions for individuals in the context of handling covid-19 in Presidential Instruction Number 6 of 2020 and Instruction of the Minister of Home Affairs Number 4 of 2020, there is no instruction instructing individuals to impose sanctions carried out by withdrawing fines in the form of money. However, Article 7 paragraph (2) letter a Mayor of Sorong Number 17 of 2020 has an arrangement to optionally withdraw monetary fines when someone suspected of violating a quo rule is not willing to carry out sanctions in the form of social work. This raises the idea that the existence of Article 7 letter a Mayor of Sorong Number 17 of 2020 has the potential or tends to reflect unlawful acts by the government (onrechtsmatigh overbeidsdaads) because a quo regulation does not have a firm administrative-legal basis and logic.

The issue regarding the existence of the content of Article 7 letter a Mayor of Sorong Number 17 of 2020 is an implementation of the policies pursued by the government. Because government policies are coercive and have certain legal consequences government policies should not harm society. Therefore it is interesting if Article 7 letter a Mayor of Sorong Number 17 of 2020 is reviewed based on law, especially in the study of State Administrative Law.

\section{Method}

This type of research was normative research supported by statutory approaches, historical approaches, philosophical approaches and conceptual approaches. The research was conducted using a literature study and then analyzed qualitatively based on primary legal 
materials (statutory regulations), secondary legal materials (library materials and scientific journals) and tertiary legal materials (legal dictionaries).

Besides, the discussion in this paper will be systematically compiled, in line with the general scientific norms. ${ }^{7}$

\section{Analysis and Discussion}

\subsection{Overview of Mayor Regulations}

The constitutional basis for the formation of regional regulations refers to Article 18 paragraph (6) of the 1945 Constitution of the Republic of Indonesia, namely "Regional governments have the right to stipulate regional regulations and other regulations to carry out autonomy and co-administration". The phrase "and other regulations" in Article 18 paragraph (6) of the 1945 Constitution of the Republic of Indonesia provides authority attributions to regional governments to form other regulations apart from Regional Regulations, the types and forms of which are adapted to various terms at the provincial and levels or regency/city.

The term mayor regulation is used to refer to regulations that are formed or stipulated by the mayor. In the P3 Law, there is no definitive definition of major regulations. However, in Article 8 paragraph (1) of the Law Number 12 of 2011, it is explained that mayoral regulation is one type of statutory regulation. In Article 1 point 26 of the Law Number 23 of 2014, as also contained in the Regulation of the Minister of Home Affairs. ${ }^{8}$ Regional head regulation is one type of regional law product in the form of a regulation, in addition to that, there is also a regional law product in the form of a decision/stipulation. Operationally a governor regional head regulation is commonly called a governor regulation, while a mayor regional head regulation is called a mayor regulation. This is also emphasized in Article 6 of the Minister of Home Affairs Regulation Number 120 of 2018, which states that the Perkada consists of governor regulations and mayor regulations. Therefore, about mayor regulations, it can be said that the mayoral regulation is a regional head regulation established and/or stipulated by the mayor.

It is stated in a scientific article that the existence of the regional head regulations is a delegation of the regional regulation in the context of implementing the regional regulation. ${ }^{9}$ However, this argument is not completely complete, because based on Article 246 paragraph (1) of the Law Number 23 of 2014, it is stated that "to implement the Regional Regulations or on the power of statutory regulations, the regional head determines the regional head regulation. In other words, the formation of a regional head regulation is not only based on the delegation from the regional regulation, but also the power of the statutory regulations. Therefore, this allows delegation of authority to occur, for example from law to regional regulations and regional head regulation. This situation can also lead to a conflict of norms because hierarchically the position of the regional regulation is higher than that of the regional head regulation. If the formation of a regional head regulation was caused by the regional regulation delegation, then this is not a problem. However, if the formation of a regional head regulation is not based on delegation from the regional regulation but from regulations whose hierarchy is higher than the regional regulation, for example, laws, then this will cause problems in the level of regulatory synchronization.

\footnotetext{
7 Sunardi Purwanda and Mira Nila Kusuma Dewi. (2020). The Effects of Monism and Pluralism on Legal Development of a Nation. Amsir Law Journal, 2(1), 23. doi: http://dx.doi.org/10.36746/alj.v2i1.30 .

8 Article 1 Number 5, Regulation of the Minister of Home Affairs of the Republic of Indonesia Number 120 of 2018.

9 Supriarno and S. Hadi. (2019). Kedudukan Peraturan Kepala Daerah dalam Kemitraan antara Pemerintah Daerah dengan DPRD. Briliant: Jurnal Riset dan Konseptual, 4(3), 323-330. doi: http://dx.doi.org/10.28926/briliant .v3i4.346 .
} 
Regional head regulation is a reflection of regional policies adopted by regional heads. At the city level, regional head regulations are commonly referred to as mayor regulations, which are a reflection of the mayor's policies based on orders from the regional regulation and the power of statutory regulations. The existence of a regional head regulation is intended to carry out regional autonomy and co-administration, as well as a further elaboration of higher laws and regulations. The Law Number 23 of 2014 is also possible if the contents of the regional regulation and regional head regulation contain material related to the local aspirations of the region as long as it is following the laws and regulations.

The legal position of regional head regulation from the point of view of state administrative law has a unique position from the point of view of state administrative law. In the tradition of State administration, a term is known, namely policy regulations (beleidsregels). In essence, policy regulations are a reflection of government policy or discretion. From a conceptual perspective, policy regulations arise as a result of a legal vacuum (rechtsvacuum), or if there is a regulation whose material is in adequate. Therefore policy regulations are also often referred to as pseudo-wetgeving (shadow regulations). The formation of policy regulations essentially functions as part of the operational administration of government. Policy regulations can be in the form of regulations or decrees. Policy regulations are formed by government organs without involving the legislature.

In Article 19 paragraph (1) of the Regulation of the Minister of Home Affairs Number 120 of 2018, it is stated that "Planning for the preparation of regional head regulations and Assembly at Provincial, Regional, or Municipal Level regulations is the authority and is adjusted to the needs of the respective institutions, commissions or agencies". This provision explains that the formation of a regional head regulation is an elaboration of policies carried out by the government without involving the legislature because it is formed based on an authority that is tailored to the needs of the institution. Thus, about the regional head regulation established by the mayor or mayor regulations, it can be concluded that mayoral regulations are regulations established/stipulated by the mayor.

\subsection{Concerning Sanctions in the Content of Mayor Regulations}

It is stated that sanctions in Arabic are termed 'iqob or "uqubah, which means "to punish someone for their sins by giving them a reward according to their deeds". ${ }^{10}$ Sanctions can also be described as rules that determine or regulate the consequences of non-compliance or violations of norms. ${ }^{11}$ The importance of the existence of sanctions in law and statutory regulations as a complement to legal rules. It is often stated in various legal science forums that without sanctions legal rules are incomplete because they lose their repressive power. In other words, sanctions are actions after the norm containing the prohibition is violated.

As already stated, the mayor regulation is a regulation established/stipulated by the major. The basis for the formation of a major regulation is to implement a regional regulation, or at the power of statutory regulations. In practice, the formation of major regulations is carried out without involving the Municipal People's Representative Council. This is because the formation of major regulations is based on the powers and needs of the forming institutions which are obtained through delegations. Based on Article 246 paragraph (2) of the Law Number 23 of 2014, the formation of a regional head regulation

${ }^{10}$ I. Bafadhol. (2015). Sanksi Dan Penghargaan dalam Pendidikan Islam. Edukasi Islami: Jurnal Pendidikan Islam. 4(8), 11181129. doi: http://dx.doi.org/10.30868/ei.v4i08.81 .

11 S. N. H. Susanto. (2019). Karakter Yuridis Sanksi Hukum Administrasi: Suatu Pendekatan Komparasi. Administrative Law and Governance Journal (ALJ), 2(1), 126-142. doi: https://doi.org/10.14710/alj.v2i1.126-142 . 
is carried out mutatis mutandis on the formation of a regional regulation, both regarding the principles of formation and content material. This means that the contents of the regional head regulation can be formed as the content of the regional regulation, except for the content on criminal provisions.

The discussion regarding the content material regarding sanctions in the regional head regulation can be said to be quite interesting. This is because the formation of a regional head regulation as stipulated in the Law Number 23 of 2014 which regulates the formation of a regional head regulation is carried out mutatis mutandis against the regional regulation, based on Article 246 paragraph (2) of the Law Number 23 of 2014, only refers to Article 237 of the Law Number 23 of 2014. Editorial Article 246 paragraph (2) of the Law Number 23 of 2014 regulates as follows, "Provisions regarding the principles of formation and content, as well as the formation of the Regional Regulation as referred to in Article 237 shall apply mutatis mutandis to the principles of formation and content, as well as the formation of regional head regulation." Meanwhile, the contents of Article 237 are as follows:

1) The principles for the formation and content of regional regulation shall be guided by the provisions of laws and regulations and the principles of law that grow and develop in society as long as they do not conflict with the principles of the unitary state of the Republic of Indonesia.

2) The formation of a regional regulation includes the stages of planning, preparation, discussion, stipulation, and enactment guided by the provisions of the statutory regulations.

3) The public has the right to provide input orally and/or in writing in the formation of regional regulation.

4) The formation of the Regional Regulation as referred to in paragraph (2) shall be carried out effectively and efficiently.

If the principle for the formation and content of the regional head regulation on referring to Article 237 of the Law Number 23 of 2014, then in fact there is no explicit provision regarding the regulation of content on sanctions in the regional head regulation. Because what is regulated in Article 237 of the Law Number 23 of 2014 is only related to:

1) The principle of formation and content material;

2) Formation stages;

3) Community involvement information; and

4) Formation is carried out effectively and efficiently.

In the formation of a regional regulation, apart from being able to contain material on criminal provisions, it can also contain material on administrative sanctions as contained in Article 238 paragraphs (4) and (5). However, this cannot be a reference in the formation of a regional head regulation, because as described above, the principles for formation and content in the formation of a Perkada only refer to Article 237 of the Law Number 23 of 2014 and not other articles.

However, in practice, many regional head regulation includes mayoral regulations which contain material on sanctions. One of them is the mayor's regulation which is the object of study in this research. However, it seems that the regulation regarding sanctions in the regional head regulation has become a custom in itself in the administrative law environment. This is because, in the dynamics of administrative law, several governmental instruments are often used in the implementation of government to solve ongoing social 
problems. Moreover, in exceptional circumstances, some of the things previously prohibited by law may result in conditionally deviating from the rules for the time being.

In the analysis conducted by Philipus M. Hadjon, the existence of sanctions in administrative law is following the purpose of the law itself. Furthermore, it is said that there is no point in including obligations or prohibitions in statutory regulations on state administration if these rules cannot be enforced by the state administration. In general, typical administrative law sanctions, namely: government coercion (bestuurdwang), favourable decision or decision making, administrative fines, and forced money by the government (dwangsom). ${ }^{12}$

\subsection{Legal Analysis on the Implementation of Health Protocol Sanctions Policy in Article 7 of the Regulation of the Mayor of Sorong Number 17 of 2020}

Mentioned in the Regulation of the Mayor of Sorong Number 17 of 2020 concerning the Implementation of Discipline and Law Enforcement of Health Protocols as Efforts to Prevent and Control Covid-2019, the formation of the Mayor of Sorong Number 17 of 2020 is due to two main considerations. First, to implement Presidential Instruction Number 6 2020, and Instruction of the Minister of Home Affairs Number 4 of 2020. Second, to increase the application of the discipline of prevention and transmission of covid-19 by imposing sanctions on violators of health protocols in connection with the increasing number of positive cases and the low compliance of the public and entrepreneurs in implementing health protocols. This mayoral regulation was enacted and promulgated on August 18, 2020.

Article 7 of the Mayor of Sorong Number 17 of 2020 regulates sanctions aimed at two subjects, namely individuals and business actors, managers, organizers or persons in charge of public places and facilities that violate health protocols. As for individual sanctions against violators of health protocols in Article 7 paragraph (2) letter of the Mayor of Sorong Number 17 of 2020, they are as follows: "Sanctions for violating health protocols in the prevention and control of Covid-19 as referred to in paragraph (1) are in the form of individuals, social work for 30 minutes and a fine of fifty thousand rupiahs to violation.

In terms of the formation of regulations by the government from the point of view of administrative law, the government or state administrative officials are given considerable authority. Based on their authority, regulations issued by the government or state administrative officials are binding and have legal consequences. Therefore, regulations issued by the government must not contain flaws that lead to illegal legal consequences. This is because government action must contain the principle of accuracy (zorgvuldigheidsbeginse). Although the regulation in Article 7 of the Mayor of Sorong Number 17 of 2020 is aimed at controlling the spread of covid-19, several things must be evaluated. Moreover, the subject of regulation from the Mayor of Sorong Number 17 of 2020 is the citizens of the city of Sorong, who during the covid-19 period had an interest in economic survival.

In the Mayor of Sorong Number 17 of 2020, there are two alternative sanctions that can be imposed on individuals who violate health protocols. First, social work for 30 (thirty) minutes. Social work is one of the sanctions in the rule of criminal law given to violators of the rules as a form of restorative justice to have a more deterrent effect on

12 P. M. Hadjon, et.al. (2008) Pengantar Hukum Adminitrasi Indonesia (Introduction to the Indonesian Administrative Law). Yogyakarta: Gadjah Mada University Press, p. 245. 
criminals, even though it is still relatively new in Indonesia. ${ }^{13}$ The social work crime also aims to overcome the negative impact of massive imprisonment efforts and to become one of the right alternatives to tackle the overcrowding that occurs in Indonesia. ${ }^{14}$ This arrangement is following the delegation of authority given by Presidential Instruction Number 6 of 2020, as well as Instruction of the Minister of Home Affairs number 4 of 2020. Second, or a fine of fifty thousand rupiahs. It is stated that the Mayor of Sorong Number 17 of 2020 is in the context of implementing Presidential Instruction Number 6 of 2020. However, if observed, Presidential Instruction Number 6 of 2020 does not give orders or delegations to local governments to prepare content related to monetary fines. In Presidential Instruction Number 6 of 2020, the sanctions that are regulated are: verbal warning or written warning, social work, administrative fines, and suspension or temporary closure of business operations. There are no orders, delegations of authority, or instructions that expressly contain norms or orders that specifically regulate the collection of monetary fines.

The content material on sanctions in Mayor of Sorong Number 17 of 2020 in its formation also refers to the attachment to the Minister of Home Affairs Instruction which regulates the format and technical guidelines for the preparation of regional head regulations in the context of implementing discipline and enforcement of health protocol laws. Even so, in fact in the Ministry of Home Affairs Instruction number 4 of 2020, the regulation regarding "administrative fines" is not imposed on individuals, but for business actors, managers, organizers or persons in charge of public places and facilities that violate health protocols. Apart from that, it is important to understand that the term "administrative fine" does not mean the same meaning as "monetary penalty". In the rule of administrative law, there is a difference between "administrative fines" which are burdensome (belastende beschikeking) and forced money by the government (dwangsom). Thus the application of "administrative fines" cannot always be applied by withdrawing forced money in the form of "monetary fines".

In legal studies, the application of administrative sanctions or fines in administrative law is an adaptation of the rules of criminal law. However, sanctions in the sense of administrative law are reparatory in nature or return to their original state, not punish them. Sanctions in the definition of "fines" can be interpreted as punishments carried out on the condition that they meet the legality principle. The principle of legality emphasizes regulatory norms or clauses. In the criteria of criminal law, it is said that it is better to free someone from legal prosecution, rather than punishing someone with unclear regulations. The relationship with Mayor of Sorong Number 17 of 2020 as described, shows that the regulation of sanctions in Mayor of Sorong Number 17 of 2020 does not begin with a strict norm order.

The policy of withdrawing monetary fines during a pandemic, especially for individuals or individuals, needs to be evaluated because it is related to the interests of the community in the economic sector. Based on data from the Statistics Indonesia of Sorong regarding the indicators of people's welfare in Sorong, it is stated that the percentage of poor people is $15.45 \%$ or as much as 39.02 thousand people. This means that for every 100 inhabitants of Sorong, 15 to 16 inhabitants are living with an expenditure of seven hundred

${ }^{13}$ J. Ginting. (2020). Sanksi Kerja Sosial Sebagai Alternatif Bentuk Pemidanaan dalam Sistem Hukum di Indonesia. Law Review, 19(3), 246-267. doi: http://dx.doi.org/10.19166/lr.v19i3.2098.

14 A. Jamilah and H. S. Disemadi. (2020). Pidana Kerja Sosial: Kebijakan Penanggulangan Overcrowding Penjara. Jurnal IUS Kajian Hukum dan Keadilan, 8(1), 26-38. doi: http://dx.doi.org/10.29303/ius.v8i1.726 . 
twenty-five thousand one hundred and seventeen rupiahs per month. ${ }^{15}$ This means that in extraordinary circumstances such as during the covid-19 pandemic, the withdrawal of administrative fines in the form of money tends to increase the economic difficulties of the community.

It should be noted that the formation of regional regulations like regional regulation or regional head regulation is prohibited from contradicting the provisions of higher laws and regulations, public interest, and morality. One of the elements "contrary to the public interest" is based on Article 250 paragraph (2) of the Law Number 23 of 2014, namely when government policies disrupt economic activities to improve community welfare. In other words, regional regulations that are against the public interest can be cancelled if they fulfil the requirements of Article 250 paragraph (2) of the Law Number 23 of 2014.

\section{Conclusion}

Regarding health protocol sanctions against individuals in Mayor of Sorong Number 17 of 2020 , alternatively in the form of social work, are sanctions following the delegation of authority given. However, the sanctions in the form of monetary fines as stipulated in Article 7 paragraph (2) letter a do not have a firm legal basis and tend to have the potential to disrupt economic activities to improve people's welfare, especially in the era of the covid-19 pandemic.

\section{References}

Books with an Author:

Hadjon, P. M., et.al. (2008) Pengantar Hukum Adminitrasi Indonesia (Introduction to the Indonesian Administrative Law). Yogyakarta: Gadjah Mada University Press.

\section{Journal articles:}

Bafadhol, I. (2015). Sanksi Dan Penghargaan dalam Pendidikan Islam. Edukasi Islami: Jurnal Pendidikan Islam. 4(8), 1118-1129. doi: http://dx.doi.org/10.30868/ei.v4i08.81 .

Ginting, J. (2020). Sanksi Kerja Sosial Sebagai Alternatif Bentuk Pemidanaan dalam Sistem Hukum di Indonesia. Law Review, 19(3), 246-267. doi: http://dx.doi.org/10.19166/lr.v19i3.2098 .

Jamilah, A., and Disemadi H. S. (2020). Pidana Kerja Sosial: Kebijakan Penanggulangan Overcrowding Penjara. Jurnal IUS Kajian Hukum dan Keadilan, 8(1), 26-38. doi: http://dx.doi.org/10.29303/ius.v8i1.726.

Purwanda, Sunardi, and Dewi, Mira Nila Kusuma. (2020). The Effects of Monism and Pluralism on Legal Development of a Nation. Amsir Law Journal, 2(1), 23. doi: http://dx.doi.org/10.36746/alj.v2i1.30 .

Supriarno and Hadi, S. (2019). Kedudukan Peraturan Kepala Daerah dalam Kemitraan antara Pemerintah Daerah dengan DPRD. Briliant: Jurnal Riset dan Konseptual, 4(3), 323-330. doi: http://dx.doi.org/10.28926/briliant .v3i4.346 .

Susanto, S. N. H. (2019). Karakter Yuridis Sanksi Hukum Administrasi: Suatu

\footnotetext{
15 Badan Pusat Statistik (BPS) Kota Sorong. (2020). Indikator Kesejabteraan Rakyat Kota Sorong Tabun 2019. Available online from: bttps://sorongkota.bps.go.id/publication/2020/10/22/4ce133e1254805ed548b6068/indikator-kesejabteraan-rakyat-kotasorong-tabun-2019.html. [Accessed October 23, 2020].
} 
Pendekatan Komparasi. Administrative Law and Governance Journal (ALJ), 2(1), 126-142. doi: https://doi.org/10.14710/alj.v2i1.126-142 .

Yunus, N. R. and Rezki, A. (2020). Kebijakan Pemberlakuan Lockdown sebagai Antisipasi Penyebaran Corona Virus Covid-19. SALAM: Jurnal Sosial \& Budaya Syar-i, 7(3): 227-238. doi: https://doi.org/10.15408/sjsbs.v7i3.15083 .

World Wide Web:

Badan Pusat Statistik (BPS) Kota Sorong. (2020). Jumlah Penduduk Menurut Jenis Kelamin dan Distrike di Kota Sorong, 2015-2019. Available from: https:/ / sorongkota.bps.go.id/ dynamictable/2018/10/09/134/jumlab-penduduk-menurut-jeniskelamin-dan-distrik-di-kota-sorong-2015---2019.html. [Accessed October 23, 2020].

Badan Pusat Statistik (BPS) Kota Sorong. (2020). Indikator Kesejabteraan Rakyat Kota Sorong Tabun 2019. Available online from: bttps:// sorongkota.bps.go.id/publication/2020/10/22/4ce133e1254805ed548b6068/indikato r-kesejabteraan-rakyat-kota-sorong-tahun-2019.btml. [Accessed October 23, 2020].

Komite Penanganan Covid-19 dan Pemulihan Ekonomi Nasional (KPCPEN). (2020). Peta Sebaran Covid-19. Available online from: https://covid19.go.id/peta-sebaran . [Accessed October 23, 2020].

KOMPAS. (2020). Data Terbaru Covid-19 Kota Sorong. Available online from: bttps:/ / wmw.kompas.tv/ article/118180/ data-terbaru-covid-19-kota-sorong.

[Accessed October 23, 2020].

\section{Conflict of Interest Statement:}

The author declares that the research was conducted in the absence of any commercial or financial relationships that could be construed as a potential conflict of interest.

Copyright (C) 2021 ALJ. All rightsreserved. 